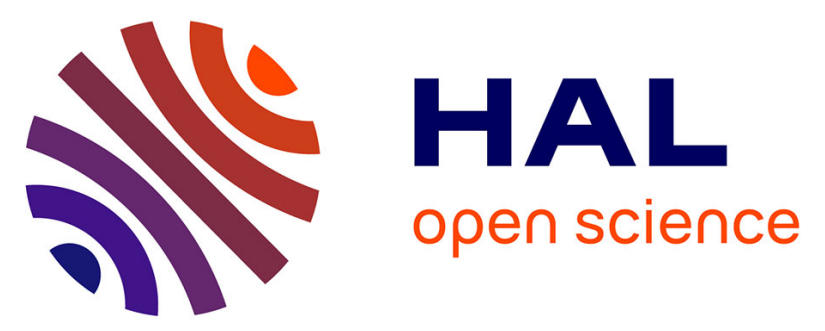

\title{
Microwave-assisted synthesis of new 2-aryl and 2-alkylimidazolones and evaluation of their in vitro anticancer activity and their in vivo toxicity on zebrafish embryos
}

Samar Bou Zeid, Aline Hamade, Fadia Najjar, François Carreaux, Samar Eid

\section{To cite this version:}

Samar Bou Zeid, Aline Hamade, Fadia Najjar, François Carreaux, Samar Eid. Microwave-assisted synthesis of new 2-aryl and 2-alkylimidazolones and evaluation of their in vitro anticancer activity and their in vivo toxicity on zebrafish embryos. Chemical Papers, 2021, 75 (6), pp.2549-2560. 10.1007/s11696-020-01502-w . hal-03156159

\author{
HAL Id: hal-03156159 \\ https://hal.science/hal-03156159
}

Submitted on 7 Apr 2021

HAL is a multi-disciplinary open access archive for the deposit and dissemination of scientific research documents, whether they are published or not. The documents may come from teaching and research institutions in France or abroad, or from public or private research centers.
L'archive ouverte pluridisciplinaire HAL, est destinée au dépôt et à la diffusion de documents scientifiques de niveau recherche, publiés ou non, émanant des établissements d'enseignement et de recherche français ou étrangers, des laboratoires publics ou privés. 
2 Microwave assisted synthesis of new 2-aryl and 2-alkylimidazolones and

3 evaluation of their in vitro anticancer activity and their in vivo toxicity on zebrafish embryos

6 Samar Bou Zeid ${ }^{1,2}$, Aline Hamade ${ }^{1}$, Fadia Najjar ${ }^{1 * *}$, Francois Carreaux ${ }^{2 * *}$, Samar Eid $^{1^{*}}$ 7

$8 \quad{ }^{1}$ Departments of Biology - Chemistry and Biochemistry, Laboratoire d'Innovation

9 Thérapeutique, Lebanese University, Faculty of sciences II, Fanar, Lebanon

$10{ }^{2}$ Université de Rennes 1, CNRS, ISCR, UMR 6226, 263 avenue du Général Leclerc, Campus de Beaulieu, 35000 Rennes, France

12

$13 *{ }^{* * *}$ and ${ }^{* * *}$ Corresponding authors,

14 E-mail addresses: s.eid@ul.edu.lb, francois.carreaux@univ-rennes1.fr, fnajjar@ul.edu.lb 15

16 Authors' contributions: All authors contributed to the study conception and design. Material 17 preparation, data collection and analys is were performed by all authors. The first draft of the 18 manuscript was written by Samar Bou Zeid and all authors commented on previous versions of 19 the manuscript. All authors read and approved the final manuscript

20

21 Received [Dates will be filled in by the Editorial office]

22

23 
Abstract

Despite the development of many treatment strategies, cancer is still considered as a

28 major cause of the death worldwide. It is therefore of great importance to elaborate more

29 effective and targeted treatment therapies. Several molecules of marine natural sources bearing 30 a 2-aminoimidazolone scaffold, such as leucettamine B and its synthetic analogs, have revealed 31 interesting spectrum of biological activity. For instance, some 2-aryl or 2-alkylimidazolones 32 have also been synthesized; however their anticancer activity was less explored. Herein we 33 describe the synthes is of five new 2-aryl and 2-alkylimidazolones derivatives via an effective 34 one-pot synthetic strategy assisted by microwave irradiations which allowed us to access the 35 product $2 \mathbf{a a}$ in a reduced time reaction compared to the thermal heating, with slightly better 36 yield (48\% compared to $45 \%)$. The new imidazolones derivatives were evaluated for their 37 potential anticancer activity in vitro against MCF-7, MDA-MB-231 and HepG2 cell lines. 38 Some of these derivatives exhibited interesting cytotoxic effects on both MCF-7 and HepG2 39 cell lines showing that this family of compounds could be considered as potential anticancer 40 agents. Furthermore, their toxic effect was evaluated in vivo on the development of zebrafish 41 embryos. The latters exhibited some morphological abnormalities when treated with high 42 concentrations of the synthesized compounds.

44 Keywords: Imidazolones derivatives, One-pot synthes is, Microwave irradiations, Anticancer 45 activity, Zebrafish embryos.

49 Cancer is a major public health problem worldwide; it is considered the second leading 50 cause of death globally (Wild et al. 2020). In particular, breast cancer is rated as the second 51 most commonly diagnosed cancer and the leading cause of cancer death among females 52 (DeSantis et al. 2017). Hepatocellular carcinoma (HCC) is considered the sixth most frequently 53 diagnosed cancer and the fourth leading cause of death from cancer in the world (Bray et al. 54 2018). Breast tumors are very heterogeneous and can be classified as tumors expressing 55 estrogen and progesterone receptors $(\mathrm{ER}+, \mathrm{PR}+)$, tumors expressing amplified human 56 epidermal receptors (HER2+) and tumors not expressing these receptors, called triple negative 57 breast (ER-, PR-, HER2-) (Dai et al. 2017). As for the HCC, studies have shown an 58 overexpression of HER2 protein in several HCC cell lines (Shi et al. 2019). Considerable efforts 
59 have been invested in establishing efficient treatment strategies of which the most commonly

60 used are surgery, radiotherapy and drug treatments (You et al. 2007; Luqmani 2005). In spite

61 of being effective in the treatment of several types of cancer, especially in the case of primary

62 tumors, these strategies can induce tumor heterogeneity resulting in the reduction of the

63 therapeutic agents efficiency and leading to treatment failure and tumor progression (Foo and

64 Michor 2014; Luqmani 2005). Thus, it is necessary to develop new targeted therapies aiming

65 specific cellular mechanisms. Many natural products classified as leads to potential drugs,

66 contribute significantly in the drug discovery and development process especially in cancer

67 treatment (Newman and Cragg 2012). As a matter of fact, marine natural products isolated from

68 marine sponges and organisms, with 1490 new products extracted and identified in 2017

69 (R. Carroll et al. 2019), are being explored for their different medical applications (Mayer et al.

70 2011; Villa and Gerwick 2010). Among these natural marine products, several molecules based

71 on a 2-aminoimidazolone core, such as leucettamine B (Boehm et al. 1993; Chan et al. 1993),

72 have shown interesting biological properties. Leucettamine B (Erreur ! Source du renvoi

73 introuvable.) and its synthetic $\mathrm{N}$-functionalized analogs have manifested significant inhibitory 74 activities against protein kinases, CLK1 (CDC (Cyclin-dependent kinase)-like kinase), and 75 DYRKs (Dual-specificity tyrosine phosphorylation-regulated kinases) (Burgy et al. 2013;

76 Tahtouh et al. 2012; Debdab et al. 2010, 2011). In the last years the imidazolone scaffold have 77 attracted attention as a potential block for the development of new effective anticancer agents 78 (Hsu et al. 2020; Abdel Gawad et al. 2016; Ling et al. 2013; Xiao et al. 2013). Moreover, 79 analogs of type 2-aryl or 2-alkylimidazolones (Erreur ! Source du renvoi introuvable.) have 80 also been synthesized (Mokale et al. 2014; Voosala et al. 2014; Shi et al. 2012; Fozooni and 81 Tikdari 2008); however, the evaluation for their anticancer activity is limited.

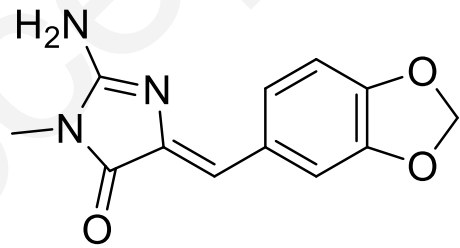

82

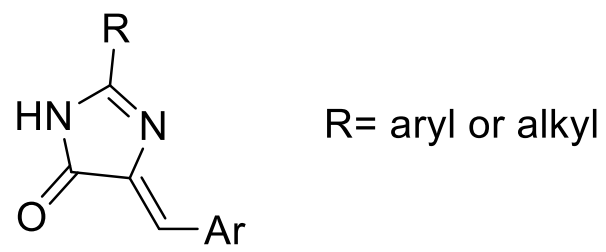

Targeted analogs

83 Fig. 1 Structure of leucettamine B and targeted 2-aryl and 2-alkylimidazolones In fact, some synthesized (Z)-2-aryl-5-arylmethylideneimidazolones were reported to 85 have potent cytotoxic effects against epithelial carcinoma cancer cell line A549 (Beloglazkina 86 et al. 2016). Eldehna et al. (Eldehna et al. 2019) also reported the synthesis and biological 87 evaluation of novel 4-benzylidene-2-phenyl-imidazolone-based benzenesulfonamides that 
88 showed anti-proliferative activity against colorectal cancer HCT-116 and breast cancer MCF-7

89 cell lines. The synthetic methodologies adopted to access these imidazolones derivatives have 90 been established on the transformation of oxazolone nuclei into imidazolone unit according to 91 several operating conditions. An efficient multi-component strategy was developed by Kidawi 92 et al. (Kidwai and Devasia 1962), involving the reaction of the ethyl ester of glycine with 93 imidate esters and aromatic aldehydes. Nevertheless, it was less adopted due to the tedious 94 preparation of imidate salts that required the passage of a continuous flow of hydrogen chloride 95 gas over a solution of the nitriles and alcohol in ether or benzene. A new method for 96 synthesizing these imidate salts by generating hydrogen chloride in situ (Yadav and Babu 97 2005), made the Kidawi's one-pot approach much more interesting. In light of the above 98 evidence and inspired by the biological activity of imidazolones derivatives, an effective one99 pot microwave assisted synthesis was applied to access a library of new 2-aryl and 2100 alkylimidazolones derivatives as potential anticancer agents (Scheme 1). This non-conventional 101 heating has emerged as an efficient green method to enhance products yield and to reduce 102 reaction time (Kappe and Dallinger 2009; Strauss and Varma 2006).

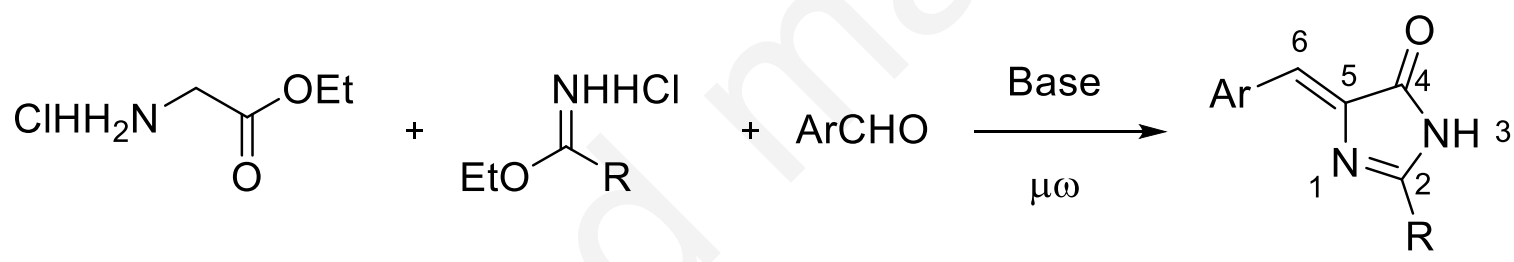

103

104 Scheme 1 Microwave-assisted synthetic strategy to imidazolones derivatives

105 The potential anticancer activity of the new compounds was then evaluated in vitro on the breast 106 cancer cell lines MCF-7, MDA-MB-231 and HCC cell line HepG2. Furthermore, we evaluated 107 their toxic effect in vivo using the zebrafish model, considered as a versatile animal model due 108 to the simplicity of its natural habitat, low cost and ease of breeding (Newman et al. 2014). The 109 ex-utero development of its transparent embryos, allowed a clear visualization of the 110 development process (Meyers 2018; Link and Megason 2008) and the evaluation of the 111 toxicological effects of the newly synthesized imidazolones on this process.

112

113

\section{Experimental}

114

Chemistry

116

117

Chemicals, reagents and instruments 
Solvents and all other chemical reagents were purchased from Acros, Sigma Aldrich

120 and Fluka and were used without further purification. Solvents were dried by refluxing with the

121 appropriate drying agents and distilled before use. Toluene was distilled over sodium and stored

122 over molecular sieves $(3 \AA)$ and ethanol was distilled over calcium hydride $\left(\mathrm{CaH}_{2}\right)$. Melting

123 points were measured on a melting point apparatus Stuart SMP10 and were not corrected. ${ }^{1} \mathrm{H}$

124 NMR spectra were recorded on BRUKER AC 300 and $\mathrm{AC} 400$ (300 and $400 \mathrm{MHz})$ and ${ }^{13} \mathrm{C}$

125 NMR spectra on BRUKER AC 300 and AC 400 (75 and $101 \mathrm{MHz}$ ) spectrometer. Chemical

126 shifts are expressed in parts per million downfield from tetramethylsilane as an internal

127 standard. Data are given in the following order: $\delta$ value, multiplicity (s: singlet; d: doublet; t:

128 triplet; q: quartet; m: multiplet; br: broad), number of protons, coupling constant $J$ is given in

129 Hertz. All high-resolution mass spectra (HRMS) were recorded on a Bruker Micro-Tof-Q II or

130 on a Waters Q-Tof 2 at the CRMPO (Centre Régional de Mesures de Physiques de l'Ouest-

131 Rennes-France) using positive ion electrospray. Reactions under microwave irradiations were

132 realized in the apparatus Anton Paar's Monowave ${ }^{\circledR} 300$ (ScanMat Platform, Rennes, France).

133 The microwave instrument consists of a continuous focused microwave power output from 0

134 to $850 \mathrm{~W}$. All experiments were performed using stirring option at $600 \mathrm{rpm}$. The target

135 temperature was reached within the required time and the chosen microwave maximal power

136 was set to $100 \mathrm{~W}$. The reaction temperature is monitored using calibrated infrared sensor and

137 the reaction time. The imidates salts 1a (Kumar et al. 2016), 1b (Yadav and Babu 2005), 1c

138 (Yadav and Babu 2005) and 1d (Shi et al. 2018) were prepared as previously described.

139 General procedure for the synthesis of 5-benzylidene-2-aryl/2-alkyl-3,5-dihydro-4H$140 \quad$ imidazol-4-one 2

141

142 Glycine methylester hydrochloride (1.5 eq), the corresponding acetimidate

143 hydrochloride $(1.1 \mathrm{eq})$ and sodium bicarbonate (3 eq) were poured in the microwave vial, 144 flushed with argon, and anhydrous toluene $(0.8 \mathrm{~mL})$ was added to the powders. To the 145 suspension was then added the aldehyde ( 1 eq), the vial was then placed in the Anton Paar 146 monowave reactor and the reaction was stirred during 15 minutes at $150{ }^{\circ} \mathrm{C}$ and at $100 \mathrm{~W}$ of 147 maximum power. After the reaction completion, the suspension was allowed to precipitate at 148 room temperature. The yellow solid obtained was collected by filtration, washed twice with 149 water, twice with cold ethanol and twice with isopropyl ether to afford the corresponding 150 imidazolone as a yellow powder. 
151 (Z)-5-(4-methoxybenzylidene)-2-phenethyl-3,5-dihydro-4H-imidazol-4-one 2aa

152 General procedure starting from $p$-methoxybenzaldehyde $(115 \mathrm{mg}, 0.85 \mathrm{mmol})$ and $1 \mathrm{a}(200$ $153 \mathrm{mg}, 0.936 \mathrm{mmol})$. Yield, 48\%; yellow solid, mp 181-183 ${ }^{\circ} \mathrm{C} .{ }^{1} \mathrm{H}$ NMR (400 MHz, DMSO, $\delta$ 154 ppm): 8.16 (d, $J=8.9 \mathrm{~Hz}, 2 \mathrm{H}), 7.30$ (d, $J=4.4 \mathrm{~Hz}, 4 \mathrm{H}), 7.23-7.17(\mathrm{~m}, 1 \mathrm{H}), 7.02$ (d, $J=8.9 \mathrm{~Hz}$, $1552 \mathrm{H}), 6.83(\mathrm{~s}, 1 \mathrm{H}), 3.82(\mathrm{~s}, 3 \mathrm{H}), 3.04(\mathrm{t}, J=7.8 \mathrm{~Hz}, 2 \mathrm{H}), 2.84(\mathrm{t}, J=7.8 \mathrm{~Hz}, 2 \mathrm{H}) .{ }^{13} \mathrm{C} \mathrm{NMR}(101$ $156 \mathrm{MHz}, \mathrm{DMSO}, \delta$ ppm): 172.1, 165.2, 161.1, 141.1, 138.6, 134.1, 128.8, 128.8, 127.4, 126.6, 157 124.5, 114.7, 55.8, 31.9, 31.6. HRMS (ESI+): $m / z$ calcd for $\mathrm{C}_{19} \mathrm{H}_{18} \mathrm{~N}_{2} \mathrm{O}_{2} \mathrm{Na}[\mathrm{M}+\mathrm{Na}]^{+}: 329.1260$, 158 found 329.1259 .

159 (Z)-5-(3-methoxybenzylidene)-2-phenethyl-3,5-dihydro-4H-imidazol-4-one $2 \boldsymbol{a b}$

160 General procedure starting from $m$-methoxybenzaldehyde $(115 \mathrm{mg}, 0.85 \mathrm{mmol})$ and $1 \mathrm{a}$ (200 $161 \mathrm{mg}, 0.936 \mathrm{mmol})$. Yield, 26\%; yellow solid, mp 172-174 ${ }^{\circ} \mathrm{C} .{ }^{1} \mathrm{H}$ NMR (300 MHz, DMSO, $\delta$ 162 ppm): 7.89 (s, 1H), 7.71 (d, $J=7.7 \mathrm{~Hz}, 1 \mathrm{H}), 7.38-7.27$ (m, 5H), 7.24-7.15 (m, 1H), 6.97 (dd, $J$ $163=7.9,2.7 \mathrm{~Hz}, 1 \mathrm{H}), 6.82(\mathrm{~s}, 1 \mathrm{H}), 3.78(\mathrm{~s}, 3 \mathrm{H}), 3.04(\mathrm{t}, J=7.7 \mathrm{~Hz}, 2 \mathrm{H}), 2.85(\mathrm{t}, J=7.7 \mathrm{~Hz}, 2 \mathrm{H})$. $164{ }^{13} \mathrm{C}$ NMR (101 MHz, DMSO, $\delta$ ppm): 172.3, 167.1, 159.7, 141.1, 140.7, 135.9, 130.0, 128.8, $165128.8,126.6,124.9,124.0,117.0,116.1,55.5,31.8,31.3$. HRMS (ESI+): $\mathrm{m} / z$ calcd for $166 \mathrm{C}_{19} \mathrm{H}_{18} \mathrm{~N}_{2} \mathrm{O}_{2} \mathrm{Na}[\mathrm{M}+\mathrm{Na}]^{+}: 329.1260$, found 329.1264 .

167 (Z)-5-(4-methoxybenzylidene)-2-(4-methoxyphenyl)-3,5-dihydro-4H-imidazol-4-one $2 \boldsymbol{b}$

168 General procedure starting from $p$-methoxybenzaldehyde $(114 \mathrm{mg}, 0.84 \mathrm{mmol})$ and $\mathbf{1 b}(200$ $169 \mathrm{mg}, 0.927 \mathrm{mmol})$. Yield, 70\%; yellow solid, mp 262-264 ${ }^{\circ} \mathrm{C} .{ }^{1} \mathrm{H}$ NMR (300 MHz, DMSO, $\delta$ $170 \mathrm{ppm}): 8.28(\mathrm{~d}, J=8.9 \mathrm{~Hz}, 2 \mathrm{H}), 8.12(\mathrm{~d}, J=8.9 \mathrm{~Hz}, 2 \mathrm{H}), 7.14(\mathrm{~d}, J=8.9 \mathrm{~Hz}, 2 \mathrm{H}), 7.06(\mathrm{~d}, J=$ $1718.8 \mathrm{~Hz}, 2 \mathrm{H}), 6.91$ (s, 1H), 3.87 (s, 3H), 3.84 (s, 3H). ${ }^{13} \mathrm{C}$ NMR (101 MHz, DMSO, $\delta$ ppm): 172 172.6, 163.0, 161.0, 159.7, 139.3, 134.2, 129.6, 127.8, 124.3, 120.9, 114.9, 114.8, 56.0, 55.8.

173 HRMS (ESI+): $m / z$ calcd for $\mathrm{C}_{18} \mathrm{H}_{16} \mathrm{~N}_{2} \mathrm{O}_{3} \mathrm{Na}[\mathrm{M}+\mathrm{Na}]^{+}: 331.1053$, found 331.1056.

174 (Z)-2-(4-chlorophenyl)-5-(4-methoxybenzylidene)-3,5-dihydro-4H-imidazol-4-one $2 c$

175 General procedure starting from $p$-methoxybenzaldehyde $(112 \mathrm{mg}, 0.826 \mathrm{mmol})$ and 1c (200 $176 \mathrm{mg}, 0.91 \mathrm{mmol})$. Yield, 64\%; yellow solid, mp 272-274 ${ }^{\circ} \mathrm{C} .{ }^{1} \mathrm{H}$ NMR (300 MHz, DMSO, $\delta$ 177 ppm): 8.29 (d, $J=8.8 \mathrm{~Hz}, 2 \mathrm{H}), 8.16(\mathrm{~d}, J=8.6 \mathrm{~Hz}, 2 \mathrm{H}), 7.67$ (d, $J=8.6 \mathrm{~Hz}, 2 \mathrm{H}), 7.07$ (d, $J=$ $1788.8 \mathrm{~Hz}, 2 \mathrm{H}), 7.01$ (s, 1H), 3.84 (s, 3H). ${ }^{13} \mathrm{C}$ NMR (75 MHz, DMSO, $\delta$ ppm): 172.4, 161.4, 179 159.2, 138.9, 137.4, 134.6, 129.6, 129.4, 127.6, 127.6, 126.2, 114.9, 55.8. HRMS (ESI+): $m / z$ 180 calcd for $\mathrm{C}_{17} \mathrm{H}_{13} \mathrm{~N}_{2} \mathrm{O}_{2} \mathrm{CINa}[\mathrm{M}+\mathrm{Na}]^{+}: 335.0557$, found 335.0556 .

181 (Z)-2-(4-bromophenyl)-5-(4-methoxybenzylidene)-3,5-dihydro-4H-imidazol-4-one $2 \boldsymbol{d}$ 
182 General procedure starting from $p$-methoxybenzaldehyde $(93.5 \mathrm{mg}, 0.687 \mathrm{mmol})$ and $\mathbf{1 d}(200$

$183 \mathrm{mg}, 0.756 \mathrm{mmol})$, Yield, 79\%; yellow solid mp 286-290 ${ }^{\circ} \mathrm{C} .{ }^{1} \mathrm{H}$ NMR (300 MHz, DMSO, $\delta$ 184 ppm): 8.29 (d, $J=8.8 \mathrm{~Hz}, 2 \mathrm{H}), 8.09$ (d, $J=8.6 \mathrm{~Hz}, 2 \mathrm{H}), 7.81(\mathrm{~d}, J=8.6 \mathrm{~Hz}, 2 \mathrm{H}), 7.07$ (d, $J=$

$1858.9 \mathrm{~Hz}, 2 \mathrm{H}), 7.03$ (s, 1H), 3.84 (s, 3H). ${ }^{13} \mathrm{C}$ NMR (75 MHz, DMSO, $\delta$ ppm): 172.3, 161.4,

$186159.2,138.9,134.5,132.5,129.5,127.8,127.5,126.4,126.2,114.9,55.8$. HRMS (ESI+): $m / z$

187 calcd for $\mathrm{C}_{17} \mathrm{H}_{13} \mathrm{~N}_{2} \mathrm{O}_{2} \mathrm{BrNa}[\mathrm{M}+\mathrm{Na}]^{+}: 379.0052$, found 379.0050 .

188

$189 \quad$ Biological activity

$190 \quad$ Cell lines: Culture conditions and viability assays

191

192 MCF-7, hormone-dependent human breast cancer, MDA-MB-231, hormone-

193 independent human breast cancer and HepG2 hepatocellular carcinoma cell lines were

194 purchased originally from ATCC (American Type Culture Collection). MCF-7 and MDA-MB-

195231 cells were routinely maintained in RPMI 1640 medium (Sigma R0883) and HepG2 in

196 DMEM high glucose medium (Sigma D0819), both medium containing 1\% penicillin

197 streptomycin (Biowest MS006W) and supplemented with 10\% Fetal Bovine Serum (Sigma

198 F9665) and 1\% L-Glutamine (Sigma G7513). The cells were cultured at $37^{\circ} \mathrm{C}$ in a humidified

199 incubator with 5\% $\mathrm{CO}_{2}$ and were passaged twice a week using 1\% trypsin (Sigma T4549). The 200 cytotoxic effects of the imidazolones derivatives were determined using the trypan blue 201 exclusion assay. It is based on the concept of dye exclusion to differentiate viable cells from 202 dead ones. Indeed, cells that possess damaged membranes are stained blue whereas viable cells 203 do not uptake the dye and remain white. MCF-7, MDA-MB-231 and HepG2 cells were seeded 204 into 24-well culture plates $(20,000 /$ well), in a total volume of $500 \mu \mathrm{L} /$ well. After overnight 205 incubation to ensure cell attachment and well-being, the medium was aspirated and cells were 206 exposed to the synthesized imidazolones in duplicate at final concentrations ranging from 0.1 207 to $60 \mu \mathrm{M}$. Stock solutions of these compounds at $30 \mathrm{mM}$ were prepared in DMSO (Sigma208 Aldrich 41640) and then diluted in culture medium to obtain the desired final concentrations. 209 The highest concentration of DMSO following dilution was $0.2 \%$ of the total volume, an 210 amount that was not toxic to the cells. Control cells were grown in culture medium. The vehicle 211 cells were treated with $0.2 \%$ of DMSO. Plates were incubated for 24,48 , and 72 hours. At the 212 end of each time point, the medium was removed; the cells were collected by the action of 213 trypsin and counted in a hemocytometer using optical microscopy. The results were presented 
214 as a percentage of the control. All measurements were performed in duplicate and each

215 experiment was repeated at least three times independently.

Animals

219 Adult wild-type zebrafish (Danio rerio) of $\mathrm{AB}$ and Casper strain of both sexes were 220 purchased from UMS AMAGEN CNRS INRA (France) and were used after ethical approval. 221 Animals were divided in $5 \mathrm{~L}$ thermostated tanks at $28 \pm 2{ }^{\circ} \mathrm{C}(15 \mathrm{fish} / \mathrm{tank})$ in a constant 222 chemical and biological controlled environment according to international standards. 223 Mechanical water filtration and aeration were also kept under constant control. Animals were 224 maintained under a 14-10 hours day/night photoperiod cycle and fed three times a day with 225 commercial flakes and live brine shrimp. Natural spawning was induced in the morning by 226 light. Embryos were then collected within $30 \mathrm{~min}$ and maintained in an E3 (1X) medium in an 227 incubator at $25^{\circ} \mathrm{C}$ to minimize stress and spontaneous deaths when treating.

228 E3 medium $(60 \mathrm{X})$ is the adequate medium for zebrafish embryos and was prepared as 229 followed: $34.8 \mathrm{~g}$ sodium chloride, $1.6 \mathrm{~g}$ potassium chloride, $5.8 \mathrm{~g}$, calcium chloride dihydrate, $2309.78 \mathrm{~g}$ magnesium chloride hexahydrate were dissolved in water with a final volume $2 \mathrm{~L}$ to 231 prepare a $60 \mathrm{X}$ stock. This solution was autoclaved before adjusting the $\mathrm{pH}$ and diluting, after 232 which it becomes compatible to use for zebrafish embryos.

234 Zebrafish embryo toxicity assay: Exposure to the imidazolones derivatives

236 Fertilized eggs of zebrafish between late blastula to early gastrula (2.5-5.25 hpf (hours 237 post-fertilization)) were sorted to ensure only eggs of the same quality were used in the 238 experiments. This was done to minimize spontaneous defects and variability between different 239 conditions. Zebrafish embryos were then transferred to 24 well plates (5 to 10 embryos per 240 well) and were maintained in 0.5 to $1 \mathrm{~mL}$ of E3 medium. Embryos were then exposed to 241 different concentrations of imidazolone derivatives $(1 \mu \mathrm{M}$ to $120 \mu \mathrm{M})$. Stock solutions of these 242 compounds at $30 \mathrm{mM}$ were prepared in DMSO and then diluted in E3 medium to obtain the 243 desired final concentrations. The highest concentration of DMSO following dilution was $0.5 \%$ 244 of the total volume. A control group (E3 1X) and a vehicle group (0.5\% DMSO) were part of 245 the experiment. Fish embryonic development was observed directly using a stereoscope, and 246 pictures were taken using the AmScope software. The malformations observed and the viability 247 rates were noted and calculated after 24,48 and 72 hours of treatment. 
253 The imidate salts used in this approach were synthesized according to the protocol 254 described by Veejendra Yadav et al. (2005). This method is based on the generation of hydrogen 255 chloride in situ following the treatment of acyl chloride with an alcohol (Scheme 2).

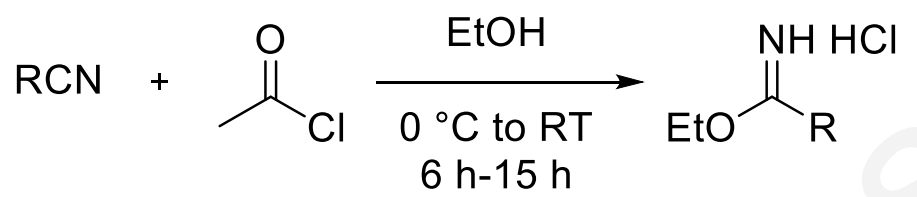

$$
\begin{aligned}
& \text { 1a } \mathrm{R}=\mathrm{PhCH}_{2} \mathrm{CH}_{2} \\
& \text { 1b } \mathrm{R}=4 \text {-methoxyphenyl } \\
& \text { 1c } \mathrm{R}=4 \text {-chlorophenyl } \\
& \text { 1d } \mathrm{R}=4 \text {-bromophenyl }
\end{aligned}
$$

257 Scheme 2 Preparation of imidate salts

258 The imidate salts were subsequently used in the preparation of 2-aryl and 2259 alkylimidazolones according to the strategy described first in 1962 (Kidwai and Devasia 1962), 260 while making modifications to the reaction conditions. It is a three-component one-pot reaction 261 involving an imidate salt, a glycine ester and an aromatic aldehyde (Scheme 3). At this stage, 262 two methods of activation of the reaction have been employed. The process was carried out 263 under conventional thermal conditions and also under microwave irradiation in order to 264 compare the two activation modes. In the interest of optimizing the conditions, the reaction was 265 conducted using $p$-methoxybenzaldehyde and compound 1a, chosen as model compounds, in 266 the presence of sodium hydrogen carbonate as base. In conventional thermal conditions 267 (toluene, $70{ }^{\circ} \mathrm{C}$ ), the product was isolated with $45 \%$ yield (in $97 \%$ of conversion) after 2 hours 268 of reaction whereas the same reaction conducted in the same conditions without solvent did not 269 result in the desired product but rather a degradation of the starting products was observed. 270 Furthermore, the reaction was conducted under microwave irradiations and the conditions were 271 optimized by variation of the heating temperature and the reaction time. In a first attempt, the 272 reaction was carried at $100{ }^{\circ} \mathrm{C}$ under $100 \mathrm{~W}$ of maximum power and for $15 \mathrm{~min}$ to yield the 273 desired product in $88 \%$ of conversion. In the next assay the temperature was increased to 150 $274{ }^{\circ} \mathrm{C}$ which resulted in a better conversion (99.7\%) and better yield (48\%) of isolated product 
275 compared to thermal heating. Finally in an attempt to achieve a greener process, the reaction 276 was conducted in a solvent-free medium in the same conditions as before; however, a decrease 277 in the conversion to $87 \%$ was noted. An increase in the heating temperature to $200{ }^{\circ} \mathrm{C}$ in a 278 solvent-free medium caused a degradation of the imidate salt and did not yield the desired 279 product. Therefore, in a final attempt, in a solvent-free medium, the temperature was maintained 280 at $150{ }^{\circ} \mathrm{C}$ and the reaction was carried for $30 \mathrm{~min}$. In these conditions the product was obtained 281 in $92 \%$ of conversion that was still lower than the conversion obtained in the presence of 282 solvent. The microwave assisted method in a solvent-based medium has proved to be more 283 efficient and suitable to reduce the reaction time and slightly enhance the yield.

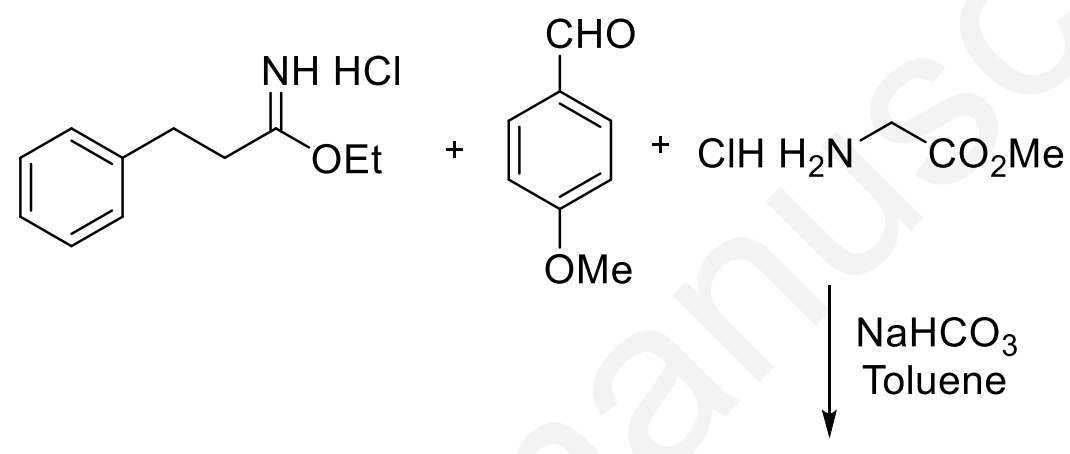

Conditions A $45 \%$

Conditions B 48\%

284

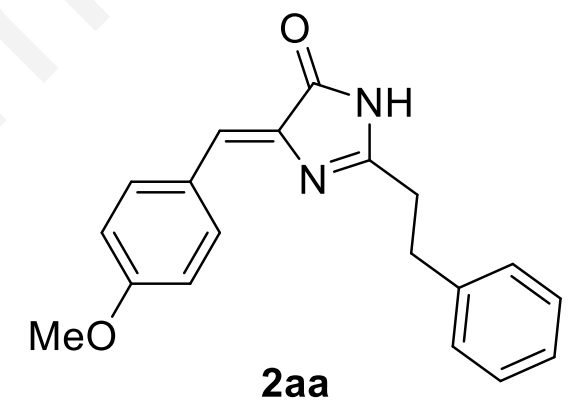

285 Scheme 3 Optimization of the one-pot process under microwave conditions, reaction 286 Conditions: (A) $72{ }^{\circ} \mathrm{C} 2$ hours, (B) $\mu \omega 150^{\circ} \mathrm{C}, 100 \mathrm{~W}, 15 \mathrm{~min}$

Subsequently, the one-pot approach was generalized to several substrates by varying 288 either the aldehyde or the salt of imidates. The reactions were carried out in the microwave 289 under the same conditions as above $\left(150{ }^{\circ} \mathrm{C}, 100 \mathrm{~W}, 15 \mathrm{~min}\right)$ leading to a small library of 290 imidazolone derivatives (Fig. 2). The desired products precipitated in the toluene and were 291 purified by a simple filtration followed by several washes in water and ether. As they were 292 insoluble in several organic solvents, it was not possible to purify them by column 293 chromatography. All compounds were obtained in a stereospecific way with retention of 294 stereochemistry and the geometry of the exocyclic double bond that was attributed as being $Z$ 
295 by the shielding effect of the carbonyl $\mathrm{C}-4$ on the olefinic proton $\mathrm{H}-5(\delta \mathrm{H}-5=6.82-7.05 \mathrm{ppm})$

296 (Debdab et al. 2010; Villemin and Martin 1995).<smiles>COc1ccc(/C=C2\N=C(CCc3ccccc3)NC2=O)cc1</smiles>

2 aa

$48 \%$

$(\alpha=99.7 \%)$<smiles>COc1cccc(/C=C2\N=C(CCc3ccccc3)NC2=O)c1</smiles>

$2 \mathrm{ab}$

$26 \%$

$(\alpha=98 \%)$

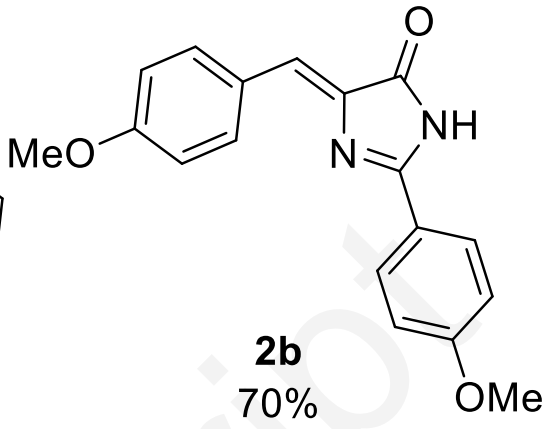

$(\alpha=97 \%)$<smiles>COc1ccc(/C=C2\N=C(c3ccc(Cl)cc3)NC2=O)cc1</smiles>

2c $64 \%$ $(\alpha=94 \%)$<smiles>COc1ccc(/C=C2\N=C(c3ccc(Br)cc3)NC2=O)cc1</smiles>

2d $79 \%$

$(\alpha=96 \%)$<smiles>O=C1NC(CCc2ccccc2)=N/C1=C\c1ccccc1</smiles>

Not isolated

$(\alpha=78 \%)$

297

298

299 Fig. 2 Yields of the 2-aryl and 2-alkylimidazolones synthetized via one-pot approach; $\alpha$ :

300 conversion percentage

301 The results showed that the one-pot reaction gives better yields by using imidate salts 302 of aryl type (2b, 2c, 2d) compared to those of alkyl type (2aa, 2ab). This observation can be 303 explained by the stability of the imidazolones formed from the aryl imidate salts, due to the 304 conjugation of the cyclic double bond with the aromatic nucleus of these salts (Kidwai and 305 Devasia 1962). It could also be explained by the fact that a small quantity of 2aa and 2ab 306 products was lost in the precipitation purification and was observed in the filtrate after filtration 307 which was not the case of compounds $\mathbf{2 b}, \mathbf{2 c}$ and $\mathbf{2 d}$. However, the difference in reactivity 308 observed within these imidates of aryl type seems to be linked to the nature of the substitue nts 309 on the aromatic ring. An electron-donor group on the aromatic nucleus promoted the 310 intramolecular cyclization of the intermediate, obtained following the addition of glycine to the 311 imidate salt, by activating the attack of the amine on the ester based on the proposed mechanis $\mathrm{m}$ 312 in the online resource. A significant decrease in yield was noticed by variation of the aldehyde 313 (2aa compared to $\mathbf{2} \mathbf{a b}$ ). This decrease can be attributed to the difference in stability of the final 
314 products obtained. Indeed, $p$-methoxybenzaldehyde induces a stability of the final product $2 \mathbf{a a}$ 315 via the conjugation of the exocyclic double bond with the aromatic nucleus, reinforced by the 316 presence of the methoxy group in the para position. This effect is absent in the case of a methoxy 317 group in the meta position (2ab). Furthermore, the absence of an activating group on the 318 aromatic nucleus of the aldehyde did not lead to total conversion. Benzaldehyde, used with 1a 319 under the same conditions as before, resulted in a $78 \%$ conversion to the final product. 320 However, attempts to purify this derivative have not been successful.

Cell viability

324 The anticancer effect of the various synthesized imidazolone derivatives was assessed 325 by means of the cell exclusion test with trypan blue against human breast cancer cell lines MCF3267 (Fig. 3) and MDA-MB-231 (Fig. 4) and against HCC cell lines HepG2 (Fig. 5). Doxorubicin 327 was used as positive control. The $\mathrm{IC}_{50}$ (concentration of the compound which caused $50 \%$ of 328 cell death) for each cell line were determined based on dose-response curves, concentrations as 329 a function of the viability percentages obtained 72 hours post-treatment. The results are 330 summarized in Table 1. It should be noted that the increased lipophilicity of compounds $\mathbf{2 c}$ and 331 2d ( $\log \mathrm{P}$ values of 3.13-3.4) caused problems in assessing their cytotoxic effect. These 332 compounds started to precipitate in the culture medium even at low concentrations $(10 \mu \mathrm{M})$; 333 therefore it was not possible to determine the exact $\mathrm{IC}_{50}$ values.

334 On breast cancer cell lines, the 2-alkyl and 2-arylimidazolones derivatives 2aa, 2ab and 335 2b ( $\log \mathrm{P}$ values of 2.44-2.93) were found to be inactive against the proliferation of the 336 hormone-independent breast cancer line MDA-MB-231. As for the hormone-dependent breast 337 cancer line MCF-7, the results show that the highest anticancer activity was observed for the 2338 arylimidazolone compound $\mathbf{2 b}\left(\mathrm{IC}_{50}=7.73 \mu \mathrm{M}\right)$ having a methoxy group in the para position 339 on each of the aromatic nuclei. As for the 2-phenethylimidazolone derivatives, compound 2aa, 340 having a methoxy substitution in the para position of the benzylidene moeity, did not show any 341 interesting cytotoxic effect $\left(\mathrm{IC}_{50}>30 \mu \mathrm{M}\right)$. 

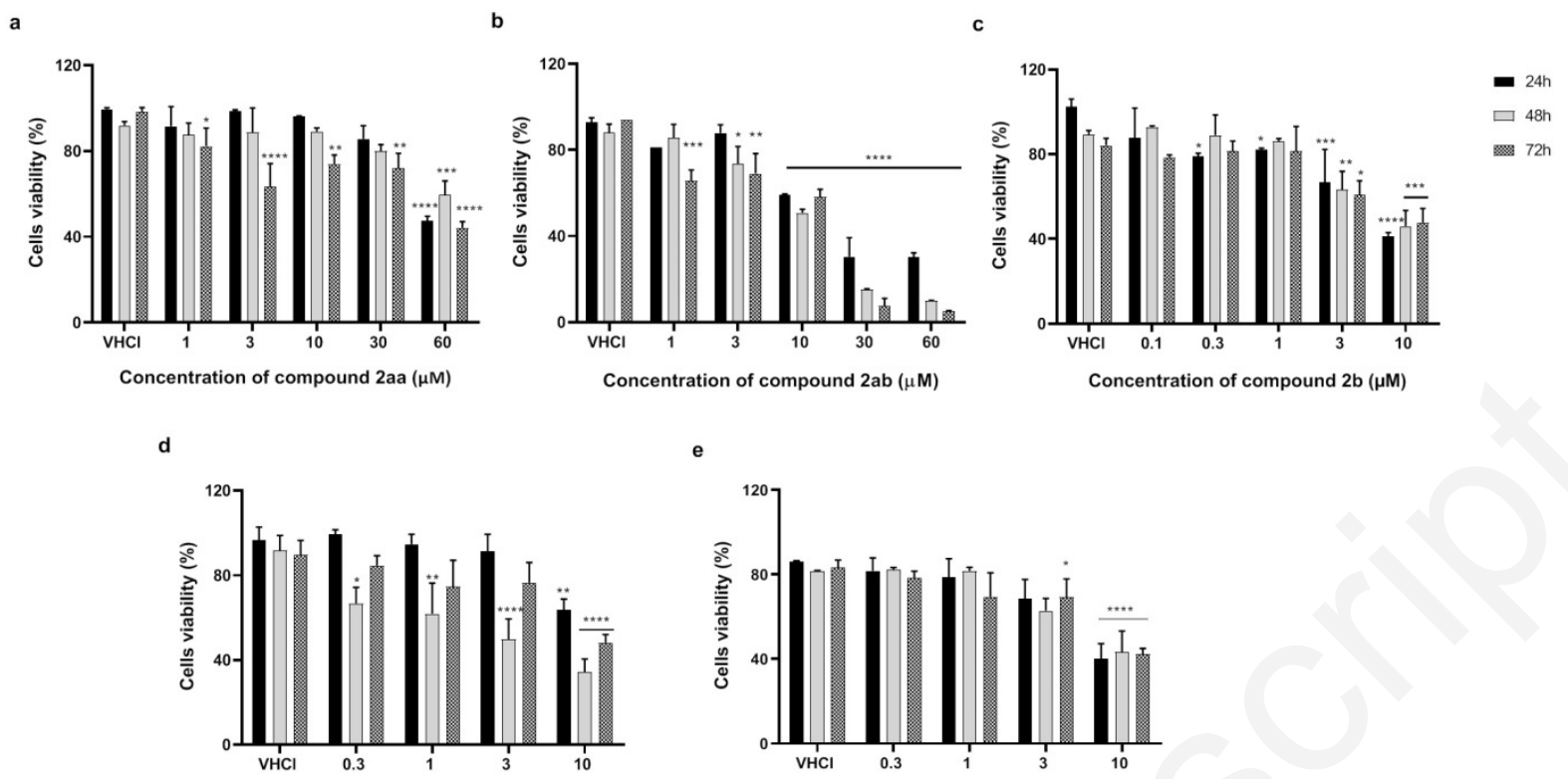

342

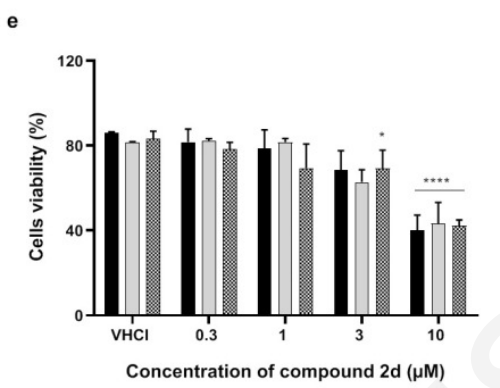

343 Fig. 3 Percentage of cell viability of the MCF-7 cell line compared to the control following 344 treatment with the different concentrations of compounds $2 a a(a), 2 a b(b), 2 b(c), 2 c(d)$ and $2 d$ 345 (e) after 24, 48 and 72 hours. Each experiment was carried out in duplicate. *, **, ***,**** 346 indicate a significant difference compared to the vehicle with $\mathrm{p}<0.05, \mathrm{p}<0.01, \mathrm{p}<0.001$ and $\mathrm{p}$ $347<0.0001$ respectively according to the ANOVA test

348 However, an enhanced cytotoxic activity was noted, when the methoxy group was displaced 349 from para to meta position in compound $2 \mathbf{a b}$, showing an $\mathrm{IC}_{50}$ of $11 \mu \mathrm{M}$.

350 Table 1 IC $_{50}$ values of compounds against different cancer cell lines

\begin{tabular}{cccc}
\hline \multicolumn{4}{c}{$\mathbf{I C}_{\mathbf{5 0}} *(\boldsymbol{\mu M})$} \\
\hline Product & MDA-MB-231 & MCF-7 & HepG2 \\
$\mathbf{2 a a}$ & $>60$ & $>30$ & 12.16 \\
$\mathbf{2 a b}$ & $>30$ & 11 & 6.8 \\
$\mathbf{2 b}$ & 26 & 7.73 & 9.47 \\
$\mathbf{2 c}$ & $>10$ & $>10$ & $>10$ \\
$\mathbf{2 d}$ & $>10$ & $>10$ & $>10$ \\
Doxorubicin & 0.01 & 0.022 & 0.046
\end{tabular}

$351 * \overline{\mathrm{IC}_{50}}$ values were derived from single dose-response curves generated from duplicate data points obtained after 72 hours of 352 treatment. 


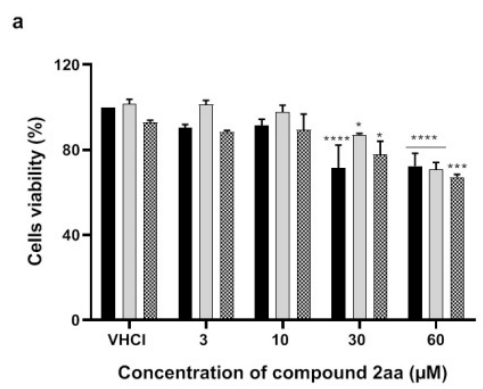

d

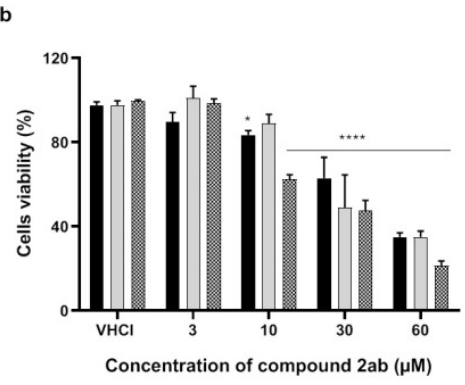

c

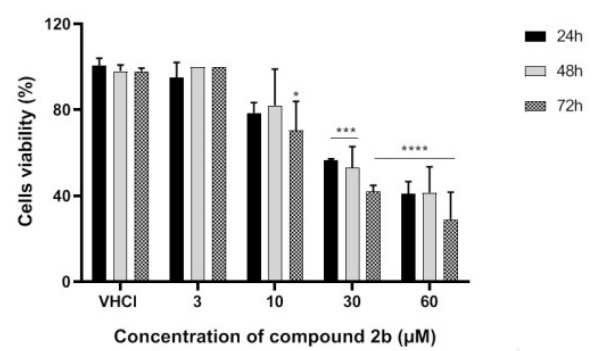

e
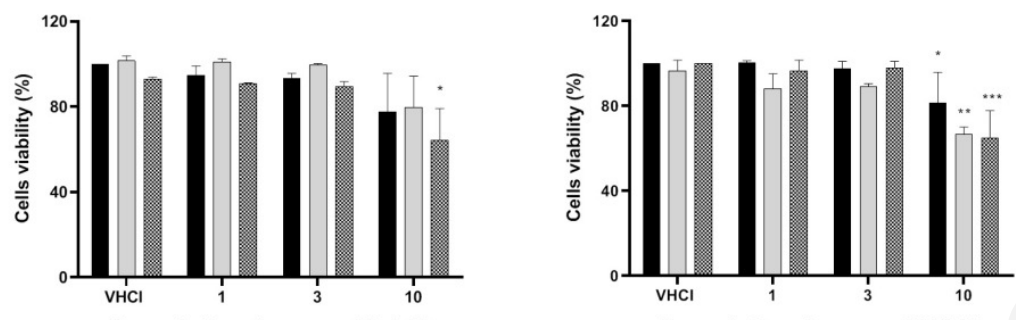

354

355 Fig. 4 Percentage of cell viability of the MDA-MB-231 cell line compared to the control 356 following treatment with the different concentrations of compounds $2 \mathbf{2 a a}(\mathrm{a}), \mathbf{2} \mathbf{a b}(\mathrm{b}), \mathbf{2 b}(\mathrm{c}), \mathbf{2 c}$ 357 (d) and 2d (e) after 24, 48 and 72 hours. Each experiment was carried out in duplicate. *, **, $358 * * *, * * * *$ indicate a significant difference compared to the vehicle with $\mathrm{p}<0.05, \mathrm{p}<0.01, \mathrm{p}$ $359<0.001$ and $\mathrm{p}<0.0001$ respectively according to the ANOVA test.

When tested on the hepatocellular carcinoma cell line HepG2, the 2361 phenethylimidazolone derivative $\mathbf{2}$ ab was found possessing the most cytotoxic activity with an $362 \mathrm{IC}_{50}$ of $6.8 \mu \mathrm{M}$. The displacement of the methoxy substitution from the meta position (2ab) to 363 the para position (2aa), reduced the cytotoxic activity by half. The 2-arylimidazolone 364 compound $\mathbf{2 b}$ also showed an interesting anticancer effect against this cell line with an $\mathrm{IC}_{50}$ of $3659.47 \mu \mathrm{M}$. Overall, the 5-benzylidene-2-alkyl and 2-arylimidazolones showed noticeable 366 cytotoxicity against MCF-7 and HepG2 cell lines. In literature, some 5-benzylidene-2367 arylimidazolones derivatives have also shown anticancer activity against epithelial carcinoma 368 cancer cell line A549 with $\mathrm{IC}_{50}$ values of 0.44 to $12 \mu \mathrm{M}$ (Beloglazkina et al. 2016). 

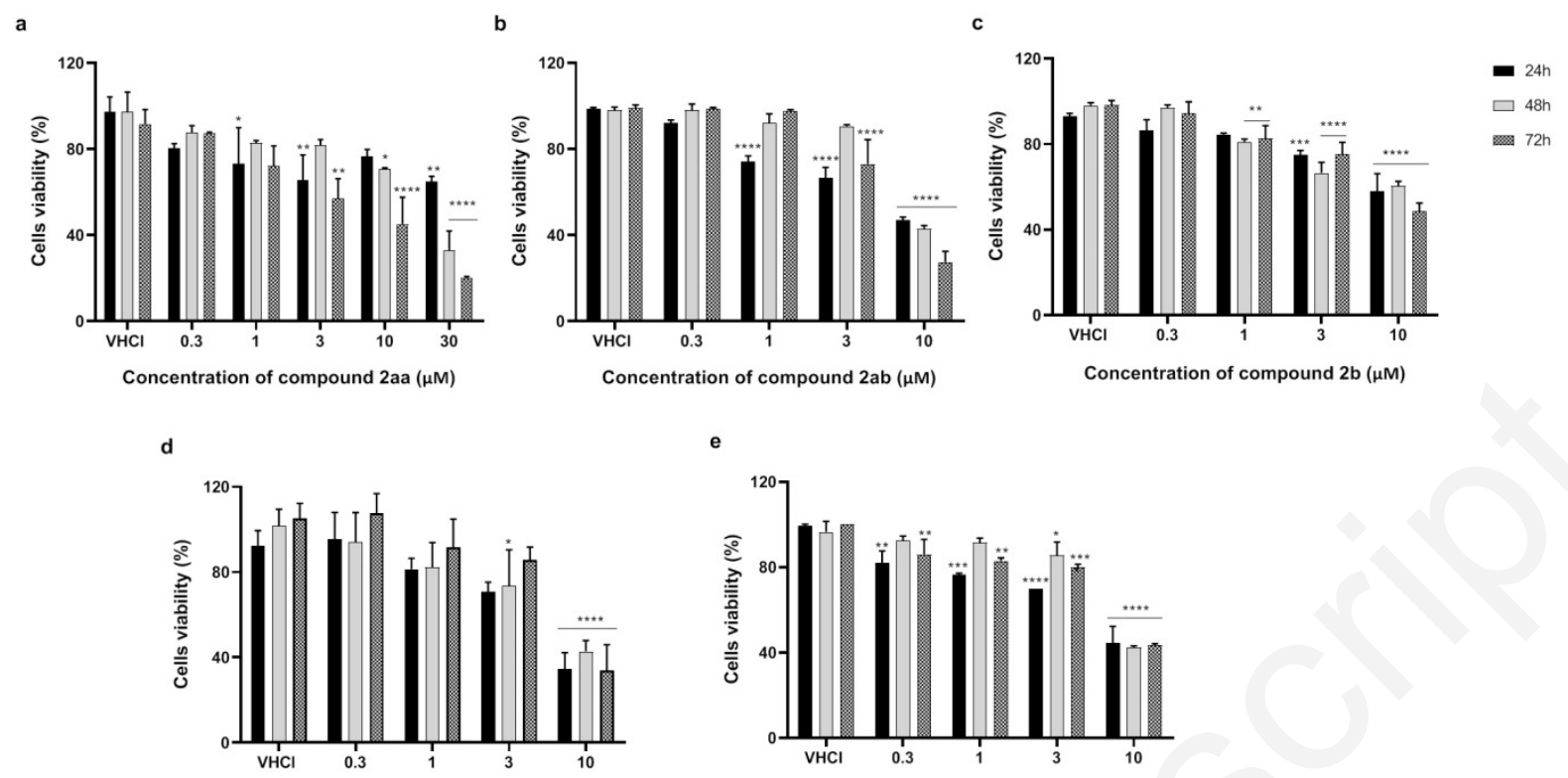

369

Concentration of compound $2 \mathrm{c}(\mu \mathrm{M})$

Concentration of compound $2 \mathrm{~d}(\mu \mathrm{M})$

370 Fig. 5 Percentage of cell viability of the HepG2 cell line compared to the control following

371 treatment with the different concentrations of compounds $2 \mathbf{a a}(\mathrm{a}), \mathbf{2} \mathbf{a b}(\mathrm{b}), \mathbf{2 b}(\mathrm{c}), \mathbf{2 c}(\mathrm{d})$ and 372 2d (e) after 24, 48 and 72 hours. Each experiment was carried out in duplicate. *, **, ***, **** 373 indicate a significant difference compared to the vehicle with $\mathrm{p}<0.05, \mathrm{p}<0.01, \mathrm{p}<0.001$ and $\mathrm{p}$ $374<0.0001$ respectively according to the ANOVA test

375 The difference of anticancer activity noted between ER+ cell line MCF-7 and HER2+ cell line 376 HepG2 on one hand and triple negative cell line MDA-MB-231 on the other hand could be 377 attributed to the different kinases expressions in these cell lines. In fact, it has been reported 378 that CLK2 is amplified and overexpressed in HER2+ and ER+ cell lines and that 379 downregulation of CLK2 inhibited breast cancer growth in cell culture (Yoshida et al. 2015), 380 whereas inhibition of hyperactive CDKs in triple negative breast cancer resulted in decreased 381 cell migration and invasion (Tarasewicz et al. 2014). These findings could suggest possible 382 selective interactions of the synthesized imidazolones derivatives with specific kinases.

383 All the imidazolones derivatives were less potent than the doxorubicin drug used as positive 384 control. However, the latter can induce acute and chronic cardiotoxicity that may occur at low 385 doses (Octavia et al. 2012). It also showed toxicity on cardiogenesis, heart formation and 386 survival of zebrafish embryos (Ma et al. 2018; Chang et al. 2014). 
The newly synthesized imidazolones derivatives and doxorubicin drug have been tested

391 for their toxic effect in vivo on the development of zebrafish embryos exposed to increasing 392 concentrations (1-120 $\mu \mathrm{M})$ of these compounds. Morphological abnormalities and mortality of 393 the embryos were studied. The summary of mortality and observed malformations of zebrafish 394 embryos at $72 \mathrm{hpf}$ with the different compounds are presented in Table 2.

395 Table 2 Percentage of mortality and types of morphological malformation caused by each 396 analog in zebrafish embryos at $72 \mathrm{hpf}$

\begin{tabular}{|c|c|c|c|c|c|}
\hline \multirow[b]{2}{*}{ Product } & \multirow[b]{2}{*}{$\begin{array}{c}\% \text { of } \\
\text { mortality } \\
\text { (at } 72 \text { hpf) }\end{array}$} & \multicolumn{4}{|c|}{ Morphological malformations at $72 \mathrm{hpf}$} \\
\hline & & Cardiac edema & Yolk sac edema & $\begin{array}{c}\text { Curved tail } \\
\text { /Short tail }\end{array}$ & $\begin{array}{c}\text { Hatching } \\
\text { retardation }\end{array}$ \\
\hline \multicolumn{6}{|l|}{$2 \mathbf{a a}$} \\
\hline 1 & 0 & - & - & - & - \\
\hline 3 & 0 & - & - & - & - \\
\hline 10 & 6 & - & - & + & - \\
\hline 30 & 10 & + & + & + & - \\
\hline 60 & 12 & + & + & + & - \\
\hline 90 & 50 & - & + & + & + \\
\hline 120 & 50 & - & + & + & + \\
\hline \multicolumn{6}{|l|}{$2 \mathbf{a b}$} \\
\hline 1 & 0 & - & - & - & - \\
\hline 3 & 0 & - & - & - & - \\
\hline 10 & 5 & - & - & - & - \\
\hline 30 & 5 & - & - & - & - \\
\hline 60 & 13 & + & + & + & - \\
\hline 90 & 15 & - & + & + & - \\
\hline 120 & 13 & - & + & + & - \\
\hline \multicolumn{6}{|l|}{$2 b$} \\
\hline 1 & 0 & - & - & - & - \\
\hline 3 & 0 & - & - & - & - \\
\hline 10 & 0 & - & - & - & - \\
\hline 30 & 10 & - & - & - & - \\
\hline 60 & 10 & - & + & + & - \\
\hline 90 & 15 & + & + & + & - \\
\hline 120 & 15 & + & + & + & - \\
\hline \multicolumn{6}{|l|}{$2 d$} \\
\hline 1 & 0 & - & - & - & - \\
\hline 3 & 0 & - & - & - & - \\
\hline
\end{tabular}




\begin{tabular}{llllll}
\hline 10 & 0 & - & - & - & - \\
\hline $\mathbf{2 c}$ & & & - & - & - \\
1 & 0 & - & - & - & - \\
3 & 0 & - & - & - & - \\
10 & 0 & - & - & - & \\
\hline
\end{tabular}

\begin{tabular}{lccccc}
\hline Doxorubicin & & - & - & - & - \\
1 & 0 & - & - & - & - \\
3 & 0 & - & - & - & - \\
10 & 20 & + & - & + & + \\
30 & 50 & + & - & + & + \\
60 & 100 & + & - & + & + \\
90 & 100 & + & - & + & + \\
120 & 100 & &
\end{tabular}

399 Below concentrations of $10 \mu \mathrm{M}$, no incidence of mortality and malformation was observed with 400 all the tested compounds. The mortality rate slightly increased after exposure to $\mathbf{2} \mathbf{a b}$ and $\mathbf{2 b}$ at 401 concentrations higher than $60 \mu \mathrm{M}$. Furthermore, treatment with 2 aa starting from $60 \mu \mathrm{M}$ caused 402 a significantly increased mortality at 48 and 72 hpf. At $72-96 \mathrm{hpf}$, there were signific ant 403 differences in the malformation phenotypes in the zebrafish embryos that were exposed to the 404 various compounds. The predominant effects observed after 2ab (Fig. 6) and 2aa (Fig. 7) 405 exposure were pericardial edema, yolk sac edema, short and contorted tail. For 2ab, starting 406 from $30 \mu \mathrm{M}$ and at $72 \mathrm{hpf}$, the length of the embryos became much shorter, whereas cardiac 407 edema, yolk sac edema and short yolk sac extension were well noted at $60 \mu \mathrm{M}$. In addition, a 408 significant contraction of the tail has been observed at $60 \mu \mathrm{M}$ (Fig. 6). However, 2aa compound 409 treatment induced tail contraction at $10 \mu \mathrm{M}$ and yolk sac and pericardial edema starting from $41030 \mu \mathrm{M}$ (Fig. 7). Furthermore, a delay in zebrafish hatching was observed only for 2aa 411 compound at high concentrations.

412 It was not possible to determine the effect of $\mathbf{2 c}$ and $\mathbf{2 d}$ compounds at high 413 concentrations due to their precipitation in the E3 medium. After 72 hours of exposure to $2 \mathbf{c}$ 414 and 2d, there were no significant mortality, neither effects on hatching delay nor malformation 415 in embryonic development, when compared with control group with all concentrations used 416 below $10 \mu \mathrm{M}$. Overall, the 5-benzylidene-2-alkyl and 2-arylimidazolones induced signific ant 417 mortality and abnormalities only at high concentrations. These compounds were less toxic on 418 the development of zebrafish embryos than doxorubin drug that caused $50 \%$ of lethality at 30 $419 \mu \mathrm{M}$. 


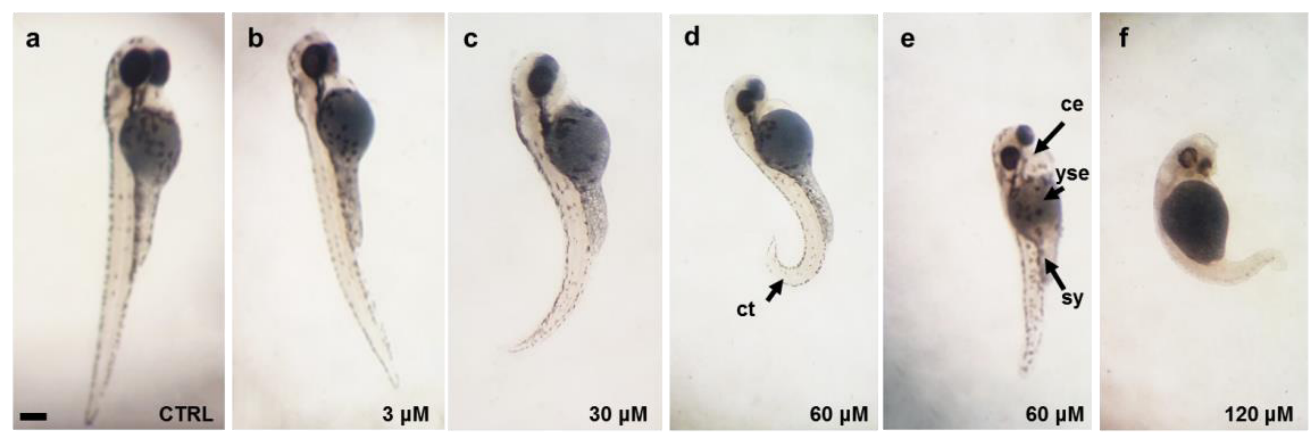

421 Fig. 6 Zebrafish embryos treated with the 2 ab product for 72 hours a) CTRL- Control; b) 422 embryo treated with $3 \mu \mathrm{M}$ c) embryo treated with $30 \mu \mathrm{M}$; d) embryo treated with $60 \mu \mathrm{M}$; e) 423 embryo treated with $60 \mu \mathrm{M}$; f) embryo treated with $120 \mu \mathrm{M}$. Scale bar $250 \mu \mathrm{m}$. ce: cardial 424 edema; yse: yolk sac edema; sy: short yolk sac extension; ct: contracted tail
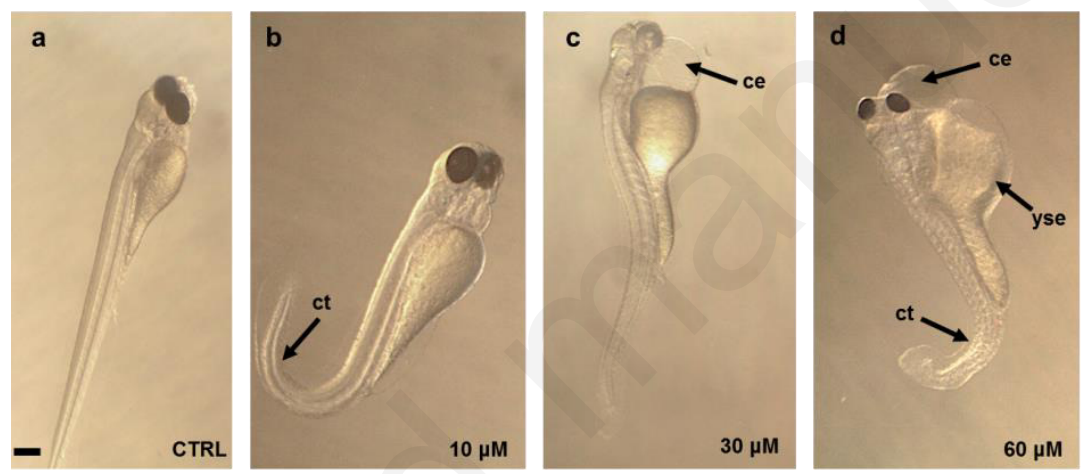

427 Fig. 7 Photos of encountered malformations, resulting from the treatment of Casper zebrafis $h$ 428 embryos with compounds 2 aa at $96 \mathrm{hpf}$.a) CTRL- Control; b) embryo treated with $10 \mu \mathrm{M} \mathrm{c}$ ) 429 embryo treated with $30 \mu \mathrm{M}$; d) embryo treated with $60 \mu \mathrm{M}$; Scale bar $250 \mu \mathrm{m}$. ce: cardial 430 edema; yse: yolk sac edema; ct: contracted tail

\section{Conclusions}

433

We optimized the synthesis of new 2-aryl and 2-alkylimidazolones derivatives, in a one435 pot procedure under microwave irradiations. The latter have shown to be more efficient than 436 thermal heating by providing similar or slightly better yields of the imidazolones while reducing 437 the reaction time from 2 hours to 15 minutes. The cytotoxicity of the imidazolones derivatives 438 was evaluated in vitro against tumor cell lines. This family of compounds exhibited interesting 439 anticancer activity against ER+ and PR+ cell line MCF-7 and HER2+ cell line HepG2. Among 440 the synthesized derivatives, compound $\mathbf{2 b}$ expressed the best cytotoxic effect against MCF-7 
441 cell line with an $\mathrm{IC}_{50}$ value of $7.73 \mu \mathrm{M}$, whereas compound 2ab was the most active against 442 HepG2 cell line with an $\mathrm{IC}_{50}$ of $6.8 \mu \mathrm{M}$. Further studies should be conducted to identify the 443 involvement of protein kinases, overexpressed in these types of tumors, in the pathways 444 responsible for the observed cytotoxicity. Besides their cytotoxic activity on cancer cell lines, 445 these compounds showed biological interactions in vivo manifested in morphological 446 abnormalities observed on the development of zebrafish embryos only at high concentrations. 447 Although a limited number of imidazolones derivatives are presented here, it is obvious that a 448 much larger diversity can be achieved through this versatile process to enrich this family of 449 molecules and subsequently conduct a more detailed SAR. This preliminary study showed that 450 this family of compounds may be considered as powerful lead molecules in the further search 451 of novel active and non-toxic anticancer agents.

452

453

454 Acknowledgements. We would like to thank the Lebanese University and the National Council 455 for Scientific Research (CNRS)-Lebanon, for the financial support of Samar Bou Zeid during 456 her thesis and for the financial support of this project. We would also like to thank the Edde 457 Association - Lebanon. The funders had no role in the study design or during data collection 458 and analysis as well as preparation of the manuscript. This work was also supported by the 459 University of Rennes 1 and by the management committee of scientific research at the Lebanese 460 university.

461

462 Compliance with ethical standards

463 Conflict of Interest: All authors declare that they have no conflict of interest.

464 Ethics approval: Adult zebrafish (Danio rerio) were used after ethical approval.

465 Consent to participate: Not applicable

466 Consent for publication: Not applicable

467 Code availability: Not applicable

468

469

Supplementary data

470

471 Electronic Supplementary Material associated with this article can be found in the online

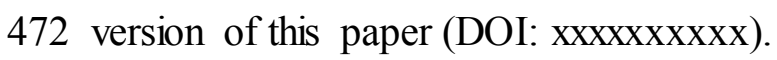


475 Abdel Gawad, N.M., Amin, N.H., Elsaadi, M.T., Mohamed, F.M.M., Angeli, A., De Luca, V., 476 Capasso, C., and Supuran, C.T. (2016). Synthesis of 4-(thiazol-2-ylamino)477 benzenesulfonamides with carbonic anhydrase I, II and IX inhibitory activity and $478 \quad$ cytotoxic effects against breast cancer cell lines. Bioorg. Med. Chem. 24 (13):3043479 3051. doi:10.1016/j.bmc.2016.05.016.

480 Beloglazkina, A.A., Wobith, B., Barskaia, E.S., Zefirov, N.A., Majouga, A.G., Beloglazkina, 481 E.K., Zyk, N.V., Kuznetsov, S.A., and Zefirova, O.N.(2016). Synthesis and biologic al 482 testing of (5Z)-2-aryl-5-arylmethylidene-3,5-dihydro-4H-imidazol-4-ones as 483 antimitotic agents. Med. Chem. Res. 25 (6):1239-1249. doi:10.1007/s00044-016-15664842.

485 Boehm, J.C., Gleason, J.G., Pendrak, I., Sarau, H.M., Schmidt, D.B., Foley, J.J., and Kingsbury, 486 W.D. (1993). Synthesis and LTB4 receptor antagonist activities of the naturally 487 occurring LTB4 receptor antagonist leucettamine A and related analogs. J. Med. Chem. $488 \quad 36(22): 3333-3340$. doi:10.1021/jm00074a014.

489 Bray, F., Ferlay, J., Soerjomataram, I., Siegel, R.L., Torre, L.A., and Jemal, A. (2018). Global $490 \quad$ cancer statistics 2018: GLOBOCAN estimates of incidence and mortality worldwide 491 for 36 cancers in 185 countries. CA. Cancer J. Clin. 68 (6):394-424. 492 doi:10.3322/caac.21492.

493 Burgy, G., Tahtouh, T., Durieu, E., Foll-Josselin, B., Limanton, E., Meijer, L., Carreaux, F., 494 and Bazureau, J.-P. (2013). Chemical synthesis and biological validation of 495 immobilized protein kinase inhibitory Leucettines. Eur. J. Med. Chem. 62:728-737. 496 doi:10.1016/j.ejmech.2013.01.035.

497 Chan, G.W., Mong, S., Hemling, M.E., Freyer, A.J., Offen, P.H., DeBrosse, C.W., Sarau, H.M., 498 and Westley, J.W. (1993). New Leukotriene B4 Receptor Antagonist: Leucettamine A 499 and Related Imidazole Alkaloids from the Marine Sponge Leucetta microraphis. J. Nat. $500 \quad$ Prod. 56 (1):116-121. doi:10.1021/np50091a016.

501 Chang, C., Wu, S.L., Zhao, X.D., Zhao, C.T., and Li, Y.H. (2014). Developmental Toxicity of 502 Doxorubicin Hydrochloride in Embryo-larval Stages of Zebrafish. Biomed. Mater. Eng. 50324 (1):909-916. doi:10.3233/BME-130885.

504 Dai, X., Cheng, H., Bai, Z., and Li, J. (2017). Breast Cancer Cell Line Classification and Its 505 Relevance with Breast Tumor Subtyping. J. Cancer 8 (16):3131-3141. 506 doi:10.7150/jca. 18457.

507 Debdab, M., Carreaux, F., Renault, S., Soundararajan, M., Fedorov, O., Filippakopoulos, P., 508 Lozach, O., Babault, L., Tahtouh, T., Baratte, B., Ogawa, Y., Hagiwara, M., Eisenre ich, 509 A., Rauch, U., Knapp, S., Meijer, L., and Bazureau, J.-P. (2011). Leucettines, a Class 510 of Potent Inhibitors of cdc2-Like Kinases and Dual Specificity, Tyrosine 511 Phosphorylation Regulated Kinases Derived from the Marine Sponge Leucettamine B: 512 Modulation of Alternative Pre-RNA Splicing. J. Med. Chem. 54 (12):4172-4186. 513 doi:10.1021/jm200274d.

514 Debdab, M., Renault, S., Lozach, O., Meijer, L., Paquin, L., Carreaux, F., and Bazureau, J.-P. 515 (2010). Synthesis and preliminary biological evaluation of new derivatives of the 516 marine alkaloid leucettamine B as kinase inhibitors. Eur. J. Med. Chem. 45 (2):805517 810. doi:10.1016/j.ejmech.2009.10.009.

518 DeSantis, C.E., Ma, J., Goding Sauer, A., Newman, L.A., and Jemal, A. (2017). Breast cancer 519 statistics, 2017, racial disparity in mortality by state. CA. Cancer J. Clin. 67 (6):439520 448. doi:10.3322/caac. 21412. 
521 Eldehna, W.M., Abdelrahman, M.A., Nocentini, A., Bua, S., Al-Rashood, S.T., Hassan, G.S., 522 Bonardi, A., Almehizia, A.A., Alkahtani, H.M., Alharbi, A., Gratteri, P., and Supuran, 523 C.T. (2019). Synthesis, biological evaluation and in silico studies with 4-benzylidene524 2-phenyl-5(4H)-imidazolone-based benzenesulfonamides as novel selective carbonic 525 anhydrase IX inhibitors endowed with anticancer activity. Bioorganic Chem. $52690: 103102$. doi:10.1016/j.bioorg.2019.103102.

527 Foo, J. and Michor, F. (2014). Evolution of acquired resistance to anti-cancer therapy. J. Theor. 528 Biol. 355:10-20. doi:10.1016/j.jtbi.2014.02.025.

529 Fozooni, S. and Tikdari, A.M. (2008). Microwave-Assisted Graphite-Support Synthes is of 530 Imidazolones. Catal. Lett. 120 (3):303-306. doi:10.1007/s10562-007-9285-4.

531 Hsu, M.-H., Hsieh, C.-Y., Kapoor, M., Chang, J.-H., Chu, H.-L., Cheng, T.-M., Hsu, K.-C., 532 Lin, T.E., Tsai, F.-Y., and Horng, J.-C. (2020). Leucettamine B analogs and their 533 carborane derivative as potential anti-cancer agents: Design, synthesis, and biological $534 \quad$ evaluation. Bioorganic Chem. 98:103729. doi:10.1016/j.bioorg.2020.103729.

535 Kappe, C.O. and Dallinger, D. (2009). Controlled microwave heating in modern organic 536 synthesis: highlights from the 2004-2008 literature. Mol. Divers. 13 (2):71. 537 doi:10.1007/s11030-009-9138-8.

538 Kidwai, A.R. and Devasia, G.M. (1962). A New Method for the Synthesis of Amino Acids. 539 Synthesis of Amino Acids and Their Derivatives through 2,4-Disubstituted 2$540 \quad$ Imidazolin-5-ones1. J. Org. Chem. 27 (12):4527-4531. doi:10.1021/jo01059a098.

541 Kumar, Y., Shaw, M., Thakur, R., and Kumar, A. (2016). Copper(II)-Mediated Aerobic 542 Oxidation of Benzylimidates: Synthes is of Primary $\alpha$-Ketoamides. J. Org. Chem. 81 $543 \quad$ (15):6617-6625. doi:10.1021/acs.joc.6b01262.

544 Ling, Y., Wang, Z.-Q., Xiao, Y.-A., Zhu, C., Shen, L., Wang, X.-M., Hui, Y., and Wang, X.545 Y. (2013). Benzylidene 2-Aminoimidazolones Derivatives: Synthesis and in Vitro 546 Evaluation of Anti-tumor Carcinoma Activity. Chem. Pharm. Bull. (Tokyo) 61 $547 \quad$ (10):1081-1084. doi:10.1248/cpb.c13-00340.

548 Link, B.A. and Megason, S.G. (2008). Zebrafish as a Model for Development., In: Sourcebook 549 of Models for Biomedical Research, P.M. Conn (ed), Humana Press, Totowa, NJ, pp. $550 \quad 103-112$.

551 Luqmani, Y.A. (2005). Mechanisms of Drug Resistance in Cancer Chemotherapy. Med. Princ. 552 Pract. 14 (Suppl. 1):35-48. doi:10.1159/000086183.

553 Ma, X., Ding, Y., Wang, Y., and Xu, X. (2018). A Doxorubicin-induced Cardiomyopathy $554 \quad$ Model in Adult Zebrafish. J. Vis. Exp. JoVE (136). doi:10.3791/57567.

555 Mayer, A.M.S., Rodríguez, A.D., Berlinck, R.G.S., and Fusetani, N. (2011). Marine 556 pharmacology in 2007-8: Marine compounds with antibacterial, anticoagulant, 557 antifungal, anti-inflammatory, antimalarial, antiprotozoal, antituberculosis, and 558 antiviral activities; affecting the immune and nervous system, and other miscellaneous 559 mechanisms of action. Comp. Biochem. Physiol. Part C Toxicol. Pharmacol. 153 $560 \quad$ (2):191-222. doi:10.1016/j.cbpc.2010.08.008.

561 Meyers, J.R. (2018). Zebrafish: Development of a Vertebrate Model Organism. Curr. Protoc. $562 \quad$ Essent. Lab. Tech. 16 (1):e19. doi:10.1002/cpet.19.

563 Mokale, S.N., Lokwani, D.K., and Shinde, D.B. (2014). Synthesis, in-vitro reverse transcriptase 564 inhibitory activity and docking study of some new imidazol-5-one analogs. Med. Chem. 565 Res. 23 (8):3752-3764. doi:10.1007/s00044-014-0954-8.

566 Newman, D.J. and Cragg, G.M. (2012). Natural Products As Sources of New Drugs over the 56730 Years from 1981 to 2010. J. Nat. Prod. 75 (3):311-335. doi:10.1021/np200906s.

568 Newman, M., Ebrahimie, E., and Lardelli, M. (2014). Using the zebrafish model for 569 Alzheimer's disease research. Front. Genet. 5. doi:10.3389/fgene.2014.00189. 
570 Octavia, Y., Tocchetti, C.G., Gabrielson, K.L., Janssens, S., Crijns, H.J., and Moens, A.L. 571 (2012). Doxorubicin-induced cardiomyopathy: from molecular mechanisms to 572 therapeutic strategies. J. Mol. Cell. Cardiol. 52 (6):1213-1225. 573 doi:10.1016/j.yjmcc.2012.03.006.

574 R. Carroll, A., R. Copp, B., A. Davis, R., A. Keyzers, R., and R. Prinsep, M. (2019). Marine 575 natural products. Nat. Prod. Rep. 36 (1):122-173. doi:10.1039/C8NP00092A.

576 Shi, F., Zeng, X.-N., Wu, F.-Y., Yan, S., Zheng, W.-F., and Tu, S.-J. (2012). Effic ient 577 microwave-assisted synthesis and antioxidant activity of 4-arylidene-2-phenyl-1H578 imidazol-5(4H)-ones. J. Heterocycl. Chem. 49 (1):59-63. doi:10.1002/jhet.766.

579 Shi, J.-H., Guo, W.-Z., Jin, Y., Zhang, H.-P., Pang, C., Li, J., Line, P.-D., and Zhang, S.-J. 580 (2019). Recognition of HER2 expression in hepatocellular carcinoma and its 581 significance in postoperative tumor recurrence. Cancer Med. 8 (3):1269-1278. 582 doi:10.1002/cam4.2006.

583 Shi, X., Wang, R., Zeng, X., Zhang, Y., Hu, H., Xie, C., and Wang, M. (2018). Ruthenium (II)584 Catalyzed Oxidant-Free Coupling/Cyclization of Benzimidates and Sulfoxonium 585 Ylides to Form Substituted Isoquinolines. Adv. Synth. Catal. 360 (21):4049-4053. 586 doi:10.1002/adsc.201800844.

587 Strauss, C.R. and Varma, R.S. (2006). Microwaves in Green and Sustainable Chemistry., In: 588 Microwave Methods in Organic Synthesis, Topics in Current Chemistry, M. Larhed, K. 589 Olofssonq (eds), Springer, Berlin, Heidelberg, pp. 199-231.

590 Tahtouh, T., Elkins, J.M., Filippakopoulos, P., Soundararajan, M., Burgy, G., Durieu, E., 591 Cochet, C., Schmid, R.S., Lo, D.C., Delhommel, F., Oberholzer, A.E., Pearl, L.H., 592 Carreaux, F., Bazureau, J.-P., Knapp, S., and Meijer, L. (2012). Selectivity, Cocrystal 593 Structures, and Neuroprotective Properties of Leucettines, a Family of Protein Kinase 594 Inhibitors Derived from the Marine Sponge Alkaloid Leucettamine B. J. Med. Chem. $595 \quad 55(21): 9312-9330$. doi:10.1021/jm301034u.

596 Tarasewicz, E., Rivas, L., Hamdan, R., Dokic, D., Parimi, V., Bernabe, B.P., Thomas, A., Shea, 597 L.D., and Jeruss, J.S. (2014). Inhibition of CDK-mediated phosphorylation of Smad3 598 results in decreased oncogenesis in triple negative breast cancer cells. Cell Cycle 13 $599 \quad$ (20):3191-3201. doi:10.4161/15384101.2014.950126.

600 Villa, F.A. and Gerwick, L. (2010). Marine natural product drug discovery: Leads for treatment 601 of inflammation, cancer, infections, and neurological disorders. Immunopharmacol. $602 \quad$ Immunotoxicol. 32 (2):228-237. doi:10.3109/08923970903296136.

603 Villemin, D. and Martin, B. (1995). Dry Condensation of Creatinine with Aldehydes Under 604 Focused Microwave Irradiation. Synth. Commun. 25 (20):3135-3140. 605 doi:10.1080/00397919508015462.

606 Voosala, C., Yarla, N.S., Nakka, M.R., and Vidavaluri, S. (2014). Facile Synthesis of 1 607 (substituted phenyl)-2-phenyl-4-(substituted benzylidine)-imidazole-5-ones and 608 Antifungal Activity Studies against Phytopathogens. Med. Chem. 4 (1):1-3. 609 doi:10.4172/2161-0444.1000156.

610 Wild, C., Weiderpass, E., and Stewart, B. (Eds.) (2020). World Cancer Report: Cancer Research 611 for Cancer Prevention. International Agency for Research on Cancer, Lyon, France.

612 Xiao, Y.-A., Wang, Z.-Q., Wang, X.-M., Hui, Y., Ling, Y., Wang, X.-Y., and He, L.-Q. (2013).

613 Synthesis and in vitro biological evaluation of novel 2-aminoimidazolone derivatives as 614 anti-tumor agents. Chin. Chem. Lett. 24 (8):727-730. doi:10.1016/j.cclet.2013.05.009.

615 Yadav, V.K. and Babu, K.G. (2005). A Remarkably Efficient Markovnikov Hydrochlorination 616 of Olefins and Transformation of Nitriles into Imidates by Use of AcCl and an Alcohol. 617 Eur. J. Org. Chem. 2005 (2):452-456. doi:10.1002/ejoc.200400591.

618 Yoshida, T., Kim, J.H., Carver, K., Su, Y., Weremowicz, S., Mulvey, L., Yamamoto, S., 619 Brennan, C., Mei, S., Long, H., Yao, J., and Polyak, K. (2015). CLK2 Is an Oncogenic 
620 Kinase and Splicing Regulator in Breast Cancer. Cancer Res. 75 (7):1516-1526. 621 doi:10.1158/0008-5472.CAN-14-2443.

622 You, Y.N., Lakhani, V.T., and Wells, S.A. (2007). The role of prophylactic surgery in cancer 623 624 prevention. World J. Surg. 31 (3):450-464. doi:10.1007/s00268-006-0616-1. 